\title{
NOTES
}

\section{CONSTITUTIONAL LAW: PRISON "NO-ASSISTANCE" REGULATIONS AND THE JAILHOUSE LAWYER}

The increasing popularity of the writ of habeas corpus, coupled with the inability of many prison inmates to effectively draft their own habeas petitions, has resulted in the emergence of a group of knowledgeable inmate practitioners willing to assist their fellow inmates in the preparation of habeas petitions and other legal papers. To counter the administrative and disciplinary problems posed by these "jailhouse lawyers," several state prison systems have adopted regulations prohibiting all inter-inmate assistance. Focusing upon the recent case of Johnson v. Avery, wherein the Sixth Circuit Court of Appeals upheld the validity of the Tennessee no-assistance rule, this note examines the statutory and constitutional problems presented by these prohibitory regulations.

$\mathbf{T}$

HE federal writ of habeas corpus is the traditional final check upon the accuracy of the judicial process, giving to a person detained the right to petition the courts for a hearing at which the legality of any aspect of his detention may be questioned. ${ }^{1}$ The increasing popularity of the writ, ${ }^{2}$ coupled with the inability of large numbers of prison inmates to draft an effective habeas corpus petition, ${ }^{3}$ has produced the "jailhouse lawyer"-the prisoner with some knowledge of habeas corpus procedure, usually gained through his own experience,

1 See generally 1 W. Barron \& A. Holtzoff, Federal Practice and Procedure $\$ 131$ (C. Wright ed. 1960); 5 J. Moore, Federal Practice I 38.34 (2d ed. 1967); R. Sokol, A HaNdBook of Federal Habeas Corpus (1965); Leighton, Federal Supremacy and Federal Habeas Corpus, 12 ST. Lovis U.L.J. 74 (1967); Note, 61 HARv. L. REv. 657 (1948). The statutory warrant for habeas corpus in the federal courts is provided by sections 2241-55 of the Federal Judiciary Act, 28 U.S.C. $\$ \$ 2241-55$ (1964).

2 The number of habeas petitions-especially those emanating from state prison inmates-filed with the federal courts has increased markedly in recent years. In 1941 the federal courts received 598 habeas corpus petitions, 127 of them from state prisoners. By 1961 the total received reached 2,314 (including motions to vacate sentence on behalf of federal prisoners), 984 from state prisoners. ADMINISTRATIVE OfFice of THE United States Courts, ANNUAL Report of the DiRector 155 (1964). In 1966 the petition figure totalled 5,853, of which 5,162 were received from inmates in state prisons. Administrative Office of the United States Courts, ANnual Report OF THE DIRECTOR 106 (1966).

${ }^{3}$ Due to ilhteracy or mental incapacity, large numbers of prison inmates are unable to exercise their right to petition for review through habeas corpus. See notes 20-28 infra and accompanying text. 
who is willing to assist fellow inmates in drafting their petitions. The Sixth Circuit Court of Appeals recently affirmed the right of prison administrators to prohibit entirely the inmate practitioner from preparing habeas corpus petitions on behalf of other prisoners. In Johnson v. Avery, ${ }^{4}$ the court upheld a Tennessee State Prison regulation which forbade any prisoner from assisting other inmates with any legal matters, including the preparation of habeas corpus petitions. ${ }^{5}$ Johnson, the petitioning inmate, had allegedly been placed in solitary confinement for eleven months for attempting to render legal assistance in violation of the above proscription. A motion for release from this confinement, heard by the district court as a petition for habeas corpus, was granted. ${ }^{6}$ In its reversal, ${ }^{7}$ the circuit court noted that the federal habeas corpus statute does not require that aid be given prisoners in the filing of their petitions. ${ }^{8}$ Further, in the court's view, the state's interest in regulating the practice of law dictated that the prison prohibition be upheld, since to allow inter-inmate assistance in legal matters would conflict with the state unauthorized practice of law statute. ${ }^{9}$ Finally, the court observed that the right to counsel has not been held an indispensable element of post-conviction proceedings ${ }^{10}$ and, further, that all recent

4382 F.2d 353 (6th Cir. 1967), cert. granted, 36 U.S.L.W. 3345 (U.S. Mar. 5, 1968) (No. 902), rev'g 252 F. Supp. 783 (M.D. Tenn. 1966).

The Guidance Manual for Prisoners, Sec. VI, page 7 provides that: "No inmate will advise, assist or otherwise contract to aid another, either with or without a fec, to prepare Writs or other legal matters. It is not intended that an innocent man he punished. When a man believes he is unlawfully held or illegally convicted, he should prepare a brief or state his complaint in letter form and address it to his lawyer or a judge. A formal Writ is not necessary to receive a hearing. False charges or untrue complaints may be punished. Inmates are forbidden to set themselves up as practitioners for the purpose of promoting a business of writing Writs." $382 \mathrm{Fr} .2 \mathrm{~d}$ at 354 n.1.

'Johnson v. Avery, 252 F. Supp. 783 (M.D. Tenn. 1966), noted in 66 CoLUM. L. REv. 1542 (1966) and 19 STAN. L. REv. 887 (1967).

382 F.2d 353 (6th Cir. 1967). The holding in Johnson, denying one inmate the services of another in the preparation of legal papers, marks a possible conflict between the decisions of the Sixth Circuit and those of the Fourth and Eighth Circuits. In Arey v. Peyton, 378 F.2d 930 (4th Cir. 1967), an inmate alleged that a rule similar to the one contested in Johnson unduly interfered with his access to the courts. The Fourth Circuit remanded the case to the district court for further inquiry, holding that prisouers unable to write or compose petitions may seek assistance from more accomplished inmates. Id. at 931 . A similar position. was apparently espoused by the Eighth Circuit in Burnside v. Nebraska, 378 F.2d 915 (8th Cir. 1967). See also White v. Blackwell, 277 F. Supp. 211 (N.D. Ga. 1967).

s 382 F.2d at 357 .

Id. at 355-57.

${ }^{10} \mathrm{Id}$. at 356. The court called special attention to the fact that decisions do not 
Supreme Court decisions concerning the right to counsel contemplate trained representation. ${ }^{11}$ The opinion concluded that effective access to legal assistance is a problem best left to the "bench, bar, and law schools."12

Jailhouse lawyers often present significant problems for prison administrators, courts, and other inmates. ${ }^{13}$ Administrators argue

require that courts furnish aid to prisoners drafting habeas corpus petitions. $C f$. Barker v. Ohio, 330 F.2d 594 (6th Cir. 1964). See also Rossmoore \& Koenigsberg, Habeas Corpus and the Indigent Prisoner, 11 Rutgers L. REv. 611, 622-24 (1957); 19 Stan. L. REv. 887, 888-90 (1967).

11 See, e.g., Miranda v. Arizona, 384 U.S. 436 (1966), discussed in Elsen \& Rosett, Protections for the Suspect Under Miranda v. Arizona, 67 ColUM. L. REv. 645 (1967) and The Supreme Court, 1965 Term, 80 HARv. L. REv. 91, 201-07 (1966) (right to counsel during custodial interrogation); Escobedo v. Hllinois, 378 U.S. 478 (1964), noted in 44 ORE, L. REv. 163 (1964) and 19 RutGers L. Rev. 111 (1964) (right to counsel when emphasis shifts from investigatory to accusatory stage); Gideon v. Wainwright, 372 U.S. 395 (1963), discussed in 31 U. CHI. L. REv. 591 (1964) and 25 U. PrrT. L. REv. 719 (1964) (right to counsel in non-capital criminal trials).

12382 F.2d at 357. The Sixth Circuit's dismissal of the problem of effective legal assistance to inmates as one best left with "the bench, bar, and law schools" was apparently made without regard to the extent such assistance is offered. That the programs of these groups fall short of meeting serious inmate needs is borne out by responses to a survey by the Duke Law Journal. For details of that survey see note 13 infra. While four of thirty-three answering states had state-funded programs employing attorneys or law students, see note 27 infra, only two states mentioned any other form of legal assistance for prisoners. Connecticut has seven legal aid societies willing to advise inmates on legal matters which are not fee generating, but no mention was made as to the procedure through which an inmate would contact one of them. Letter from Warden Fredrick G. Reincke, Connecticut State Prison, to the Duke Law Journal, Dec. 1, 1967. North Dakota has a voluntary arrangement with the local county bar association, whose members visit the prisoners on an alphabetical basis. Letter from Charles F. Enders, North Dakota State Penitentiary, to the Duke Law Journal, Nov. 17, 1967. While Mississippi reports that its prisons usually have inmates who were formerly licensed attorneys, Letter from C.E. Breazeale, Superintendent, Mississippi State Penitentiary, to the Duke Law Journal, Oct. 16, 1967, their expertise would be of no value to fellow prisoners if the prison adopted a noassistance rule as Tennessee had done in Johnson. Federal district courts will appoint counsel whenever need for such assistance appears from the petition, Letter from Robert Van Pelt, Judge, United States District Court for Nebraska, to the Duke Law Journal, Nov. 7, 1967, but these courts are hesitant to request assistance from practicing attorneys since no provision exists for payment of court-appointed counsel. Further, the method employed in federal courts presupposes an effective inmate-prepared petition. Nebraska is also contemplating an arrangement by which senior law students at the University of Nebraska would aid and advise prisoners, Letter from Robert Van Pelt, supra, but at least one prison administrator finds utilization of law students more burdensome than reliance on jailhouse lawyers, Letter from Ben L. Garris, Associate Warden, Louisiana State Penitentiary, to the Duke Law Journal, Nov. 13, 1967. Thus it would seem that the judiciary, bar associations, and law schools are not at present providing the assistance to prisoners assumed by the Sixth Circuit's decision.

${ }^{18}$ See Price v. Johnston, 334 U.S. 266, 296-97 (1948) (Jackson, J., dissenting); Goodman, Use and Abuse of the Writ of Habeas Corpus, 7 F.R.D. 313, 315-16 (1947). 
that these practitioners encourage attitudes inimical to rehabilitation by criticizing the administration and its policies, establishing an inmate hierarchy, ${ }^{14}$ dominating the weaker and more naive inmates, ${ }^{15}$ and focusing the attention of prisoners upon an often false hope of release. ${ }^{16}$ Since the jailhouse lawyer has few other demands upon his time, he produces a proliferous bulk of pleadings, petitions, writs, and motions which add to the already serious problem of overcrowded court dockets. ${ }^{17}$ In addition, the task of the judiciary in

The following conditions were described by one prison administrator: "At any given time, the penitentiary has about $\mathbf{1 5 0}$ men who are very hostile to authority, bitter about their sentences, sophisticated in criminality and court processes, and thus compose a rather hard-core jailhouse lawyer group. About fifty of them are so decply involved in their legal activity that they have two or three cases going at the same time, chal. lenging not only their own criminal cases but through the court proccsses challenging the rules and regulations of the institution, constitutionality of [state] laws, qualifications of the sentencing judge and prosecuting attorney, etc." Letter from George W. Randall, Administrator, Oregon State Board of Control, to the Duke Law Joutrnal, Oct. 19, 1967.

The above letter was one response to a survey undertaken by the Duke Law Journal in connection with this note. Letters were sent to heads of penal institutions in all state and federal jurisdictions, seeking information concerning the average cducational achievement, intelligence, and literacy among inmates. Material relating to those categories is included in the appendix, while responses discussing problems connected with jailhouse lawyers or suggestions for providing legal assistance to inmates are incorporated into the text or footnotes.

Thirty-three replies were received from fifty-one inquiries sent. All correspondence is on file in the offices of the Duke Law Journal.

${ }^{14}$ See Hatfield v. Bailleaux, 290 F.2d 632, 639 (9th Cir.), cert. denied, 368 U.S. 862 (1961), noted in 58 Mrch. L. REv. 1233 (1960) and 39 TEXAs L. REv. 228 (1960).

${ }^{16}$ Letter from Frank A. Eyman, Superintendent, Arizona State Prison, to the Duke Law Journal, Nov. 7, 1967; Letter from George W. Randall, Administrator, Oregon State Board of Control, to the Duke Law Journal, Oct. 19, 1967; Linde, Let's Disbar the Jail House Lawyer, Procendings of THE AM. CoRRectional Ass'N 124, 127 (1962). There is general agreement among prisoners and administrators that a rule against the payment of fees for work done by the jailhouse lawyer is difficult to enforce. Such work is often done for barter items, such as cigarettes. Letter from James H. Noe, Virginia State Penitentiary \#81178, to the Duke Law Journal, Nov. 1, 1967; Letter from Frank A. Eyman, supra; Letter from Gcorge W. Randall, supra.

${ }^{18}$ An example of the false hopes generated by jailhouse lawyers is the case of Williams v. Beto, 354 F.2d 698 (5th Cir. 1965). The defendant refused to allow his court-appointed attorney to appeal his conviction to a higher state court. He felt he could more easily secure release from the Hunstville State Prison because "tbey've got some boys down there that are authorities on writs of habeas corpus." Id. at 702.

${ }^{17}$ The District of Columbia Circuit once angrily noted that, during a 5-ycar period, 119 inmates managed to present 597 petitions to that court. One inmate alone pro. duced 50 separate petitions for habeas corpus. See Dorsey v. Gill, 148 F.2d 857, 862 . 63 (D.C. Cir.), cert. denied, 325 U.S. 890 (1945). Prison administrators responding to the Journal survey complained of the large amount of legal papers and petitions produced by small numbers of inmates. One revorted example concerned a prisoner con. ducting post conviction and habeas corpus proceedings in his own criminal case, challenging divorce proceedings brought by his wife, contesting a child adoption suit, and pressing four different suits against the warden and various penitentiary regula- 
discerning meritorious claims is often made more difficult by the legal myths and misconceptions propagated in the jailhouse lawyer's work.18 Since that work may often be of poor legal quality, it is the illiterate inmate being assisted who may ultimately suffer if his meritorious claim is not heard or understood.19

Despite the problems created by jailhouse practitioners, they may fulfill-although inadequately-significant needs within their prison society. The conclusion is inescapable that prisoners generally are far less prepared than the average citizen for the task of drafting the type of petition necessary to gain judicial attention. The average citizen has the equivalent of a high school education,,${ }^{20}$ while in most

tions. These actions were proceeding simultaneously in seven different courts. Furthermore, in addition to his own work, the inmate was employing three attorneys on his various projects. Letter from George W. Randall, Administrator, Oregon State Board of Control, to the Duke Law Journal, Oct. 19, 1967. An inmate contacted by the Joumal, though confessedly in the minority, felt that some means of control should be exercised to keep prisoners' groundless petitions from cluttering the courts. He based his opinion upon observations that some inmates do in fact produce knowingly frivolous petitions which advance grounds that cannot possibly be supported at a hearing. Letter from James H. Noe, Virginia State Penitentiary \#81178, to the Duke Law Journal, Nov. 1, 1967.

${ }_{18}$ "Not less important . . . is the problem presented by the character of the petitions themselves. Much of the judges' time is spent in trying to decipher and interpret the chaotic papers that come to them from prison inmates. Many of the petitioners are illiterates, or persons of limited education who depend upon 'jail-house lawyers' for assistance in preparing these documents. Not only are such practitioners notoriously unreliable, but their work product is often a mass of confused and incomprehensible legal mumbo-jumbo. Judges have no way of knowing from a reading of the papers whether the prisoner has merely copied language from other cases, wholly dissimilar from his case, or has something worthwhile to allege, but is inept due to his lack of legal training." Habeas Corpus and Post Conviction Review, Report of the Committee on Habeas Corpus, 33 F.R.D. 363, 384-85 (1963).

Prisoners often hear of new cases through newspapers or rumor within the prison, and many seem to think that cases from other jurisdictions, though factually distinguishable, will serve as a basis for their release. One such rumor claimed that constitutional provisions against double jeopardy were violated by a trial for an escape after accumulated good time had been taken away or the escapee had been placed in solitary confinement. Inmates in Wisconsin fully expected that the case of In re Maddox, 351 Mich. 358, 88 N.W.2d 470 (1958), which held that Michigan inmates confined without trial under that state's sexual psychopath law could not be confined as criminals, would apply to secure their release. Note, Legal Services for Prison Inmates, 1967 WIS. L. REV. 514, 516-17.

${ }^{10}$ See Whitley v. Cunningham, 205 Va. 232, 135 S.E.2d 823 (1964), in which the court granted a petition, apparently drafted by another prisoner, despite "untrue and irresponsible" allegations. Reliance upon fellow prisoners may occasionally cause a prisoner to fail to pursue other reliable channels for relief, see note 16 supra, although professionally trained assistance is not always readily available, see note 12 supra. See also Linde, supra note 15 , at 124-25.

${ }^{\circ}$ U.S. Dep'r of Commerce, Bureau of the Census, Statistical Abstract of the United Srates 113 (1966) [hereinafter cited as 1966 Statistical Abstract]. 
states the average prisoner has spent only eight years in school.21 Although two percent of the national population is classified as illiterate, ${ }^{22}$ many prison systems report a substantially higher percentage of illiteracy. ${ }^{23}$ Approximately one half of one percent of the population at large is mentally defective; 24 yet representative state samplings show that almost three times as many prisoners suffer from mental deficiencies. ${ }^{25}$ Hence, a large segment of the prison population is unable to write even the short, simple factual statement required to initiate review through habeas corpus. ${ }^{20}$ Also, because

${ }^{21}$ See appendix. The state reporting the highest average educational level in the survey was Washington, whose inmates have a median education level of 9.8 years. Letter from Washington State Department of Institutions, to the Duke Law Journal, Nov. 19, 1967. The lowest education achievement reported was in Alabama, with 4.5 years average schooling per inmate. Letter from A. Frank Lee, Commissioner, Alabama Board of Corrections, to the Duke Law Journal, Oct. 9, 1967. It is interesting to note that tests universally indicated a lower level of achievement than that claimed in statistics showing the number of years of school attended. When both figures are given, discrepancies approaching four years are possible. For example, North Carolina reported median school attendance of $\mathbf{8 . 3 3}$ years, while achicvement testing indicated a median of 4.57 years. Letter from Frank A. Hall, Administrative Assistant, North Carolina Department of Correction, to the Duke Law Journal, Nov. 28, 1967.

221966 Statistical Abstracr 116.

${ }^{28}$ Louisiana: $16 \%$ of all inmates are illiterate. Letter from Ben L. Garris, Associate Warden, to the Duke Law Journal, Nov. 13, 1967. Oregon: $14 \%$ are illiterate at admission. Letter from George W. Randall, Administrator, Oregon State Board of Control, to the Duke Law Journal, Oct. 19, 1967. Texas: $16 \%$ of the prisoners are illiterate. Letter from Dr. George Beto, Director, State Department of Corrections, to the Duke Law Journal, Nov. 17, 1967. For a complete list of the illiteracy in all state prisons responding to the survey see appendix. States reported illiteracy among inmates within a wide range. Delaware reported $40 \%$ illiteracy among prisoners, Letter from Dr. William Nardini, Commissioner, Delware Deparmtent of Corrections, to the Duke Law Journal, Nov. 14, 1967, while Minnesota reported only $1 \%$ of all inmates illiterate, Letter from James N. Bradford, Special Assistant Attorney General, Minnesota Department of Corrections, to the Duke Law Journal, Nov. 13, 1967, which is only one-half of the national illiteracy rate. See note 22 supra and accompanying text. Figures showing an illiteracy rate among prisoners lower than the national average are naturally suspect unless accompanied by some explanation, as in the case of Oregon. See appendix. Some literacy figures are doubtless based on definitions that are not meaningful for the purpose of this note, since the ability to draft a habeas corpus petition may require more than mere functional literacy.

${ }^{24}$ See 1966 Statistical Abstract 77.

${ }^{25}$ Florida officials reported that $1.2 \%$ of that state's prison inmates were mentally disabled. Letter from Jack D. Straubing, Administrative Assistant, Florida Division of Corrections, to the Duke Law Journal, Oct. 13, 1967. Minnesota: 4\%, Letter from James N. Bradford, Special Assistant Attorney General, Minnesota Department of Corrections, to the Duke Law Journal, Nov. 13, 1967. Oregon: 1\%, Letter from George W. Randall, Administrator, Oregon State Board of Control, to the Duke Law Journal, Oct. I9, 1967. Wisconsin: 1.2\%, Letter from John G. Stoddard, Wisconsin Institutional Services, to the Duke Law Joumal, Oct. 20, 1967. For a comparison of mental disability in all reporting states see appendix.

${ }^{26} \mathrm{See} 252 \mathrm{~F}$. Supp. at 787. 
of his confinement, the illiterate prisoner usually is unable personally to contact an attorney; and few lawyers voluntarily visit the prison to provide inmates the needed assistance. Furthermore, most prisons do not provide any type of free legal services on a regular basis. ${ }^{27}$ Consequently, in many jurisdictions the inmate lawyer provides the only means of assistance for the illiterate or semi-literate prisoner who wishes to petition for habeas corpus. ${ }^{28}$

The lower court in Johnson, acutely aware of the illiteracy problem, ${ }^{20}$ held the prison regulation in question invalid as conflicting with a right to assistance in the preparation of habeas corpus petitions granted by section 2242 of the Judiciary Act. ${ }^{30}$ The pre-

${ }^{27}$ Of thirty-three responses to the survey conducted in connection with this note, only five states reported free legal services of any type. Oregon, Minnesota, and New Jersey have employed a staff of trained attorneys who represent the prisoners as public defenders. Letters to the Duke Law Journal from George W. Randall, Administrator, Oregon State Board of Control, Oct. 19, 1967; James N. Bradford, Special Assistant Attorney General, Minnesota Department of Corrections, Nov. 13, 1967; and Lloyd W. McCorkle, Commissioner, New Jersey State Department of Institutions and Agencies, Nov. 22, 1967. The Oregon program is discussed in notes 80-81 infra and accompanyiug text. Texas employs two senior law students each summer to advise inmates, Letter from Dr. George Beto, Director, Texas Department of Corrections, to the Duke Law Journal, Nov. 17, 1967, while North Dakota has a voluntary arrangement with the county bar association to provide free legal advice to inmates by sending the attorneys to the prison on an alphabetical basis. Letter from Charles F. Enders, North Dakota State Penitentiary, to the Duke Law Journal, Nov. 17, 1967.

${ }^{28}$ The court of appeals seemingly failed to grasp the magnitude and immediacy of this problem. The court stated: "The main thrust of the District Court's opinion on this issue was that the petitioner's services are needed to make other prisoners' rights to habeas corpus effective in light of their own limited abilities. We believe that on closer analysis this right to effective post-conviction procedures does not warrant so drastic a limitation on the power of the state to regulate discipline in its penal institutions and to control the practice of law within its borders." 382 F.2d at 356 . However, review of relevant statistics tends to reinforce the original conclusions of the district court. See appendix.

${ }^{20}$ The language of the district court clearly showed an understanding of the problems faced by many inmates, as seen in the following: "From the Court's experience with habeas corpus petitions, it is apparent that without the assistance of some third party, many prisoners in the state penitentiary would be totally incapable of preparing an intelligible petition, letter or request on their own behalf. The respondent does not deny this, but asserts that the solution is for such a prisoner to contact a licensed attorney to act in his behalf. Of course, the same incapacities (sub-standard intelligence, inability to write, etc.) which make it impossible for a prisoner to draft a meaningful habeas corpus petition also make it impossible for nim to draft a letter whieh would be sufficient to arouse the attorney's interest. Furthermore, few indeed would be the lawyers who would volunteer to represent such prisoners, the great majority of whom are totally indigent.

For all practical purposes, if such prisoners cannot have the assistance of a 'jail-house lawyer,' their possible valid constitutional claims will never be heard in any court." 252 F. Supp. at 784.

so "Clearly, by the instant regulation, the prison officials have interfered with the statutory right of prisoners, incapable of acting for themselves, to have someone act on 
decessor of section 2242 required that the petition be "in writing signed and verified by the person for whose relief it is intended." 31 However, under the old statute some courts allowed an individual to petition for a writ of habeas corpus on behalf of a second party whenever it could be adequately shown that the petition was authorized by the second party and that party was, due to some physical or mental handicap, incapable of personally filing the petition. ${ }^{32}$ The legislative history of the 1948 amendment to section 2242 indicates that the revisors, by adding the words "or by someone acting in his behalf" to the old statute, intended to incorporate this liberal secondparty practice. ${ }^{33}$ Citing the 1948 revision of the statute, the district

their behalf just as surely and effectively as if the officials had made it an offense for such prisoners to request such assistance. No matter how it is analyzed, the effect of the prison regulation now in question is to deprive these prisoners of their federal statutory right to have a habeas corpus petition filed on their behalf by a third party." 252 F. Supp. at 785 (emphasis in original).

Section 2242 reads as follows:

"Application for a writ of habeas corpus shall be in writing signed and verified by the person for whose relief it is intended or by someone acting in his behalf.

"It shall allege the facts concerning the applicant's commitment or detention, the name of the person who has custody over him and by virtue of what claim or authority, if known.

"It may be amended or supplemented as provided in the rules of procedure applicable to civil actions.

"If addressed to the Supreme Court, a justice thereof or a circuit judge it shall state the reasons for not making application to the district court of the district in which the applicant is held." 28 U.S.C. $\$ 2242$ (1964) (emphasis added).

${ }^{31}$ Federal Habeas Corpus Act, ch. 13, $\$ 754,18$ Stat. 142 (1878).

${ }^{32}$ See Collins v. Traeger, 27 F.2d 842, 843 (9th Cir. 1928); United Statcs $a x$ ral. Bryant v. Houston, 273 F. 915, 916-17 (2d Gir. 1921); Ex parte Dostal, 243 F. 664, 668 (N.D. Ohio 1917); United States ex rel. Funaro v. Watchorn, 164 F. 152, 153 (S.D.N.Y. 1908). In Fouston the court broadly asserted in dicta that, due to English common law precedents, second party writs are permissible in many cases where it is neither possible nor feasible for the detained party himself to execute the writ. $273 \mathrm{~F}$. at 916, citing In re Ferrens, 8 F. Cas. 1158 (No. 4746) (C.C.S.D.N.Y. 1869). The Funaro case allowed a petition to be presented by the attorney of a party facing deportation. The court mentioned in dicta other situations compelling the acceptance of second party petitions, notably the infancy or incompetency of the party detained, or a lack of time in which to act. It should be noted that the above cases required that the petition explain why the person in custody did not himself present the petition. See Gusman v. Marrero, 180 U.S. 81, 87 (1901). Sac also Wilson v. Dixon, 256 F.2d 536 (9th Cir.), cert. denied, 358 U.S. 856 (1958), in which the court refused to hear a petition drafted for one inmate by another prisoner. The court cmpliasized that the inmate in whose behalf the petition was submitted was already represented in other proceedings by competent counsel. Id. at 537-38.

${ }^{38}$ The entire relevant legislative history of the 1948 revision of $\$ 2242$ is containcd in the following few lines: "Words 'or by some one acting in his behalf' were added. This follows the actual practice of the courts, as set forth in United Stales ex ral. Funaro v. Watchorn, C. C. 1908, 164 F. 152; Collins v. Traeger, C.C.A. 1928, 27 F.2d 842, and cases cited." H.R. REP. No. 308, 80th Cong., 1st Sess, A178 (1947). See note 32 supra. 
court held that the Tennessee prison regulation conflicted with the federal statutory right to assistance granted by the amended section 2242.34 The district court holding, in effect, legitimatized the limited practice of jailhouse lawyers where states have failed to provide any alternative means of assistance. $^{35}$ Reversing, the Sixth Circuit contended that the amended language of section 2242 referred only to the act of signing and verifying the petition, and not to its drafting or preparation. ${ }^{36}$ According to the circuit court, the "incapacity" contemplated by the statute meant physical or mental handicaps which prevented the inmate from authenticating, rather than initially preparing, the petition. ${ }^{37}$

While the Sixth Circuit denied that section 2242 grants an inmate a right to assistance in the preparation of habeas petitions, the court conceded that the section does authorize a second party to sign or verify the petition. The court apparently interpreted section 2242 as conferring standing upon a representative acting in behalf of the prisoner. ${ }^{38}$ If the petition adequately explains the necessity for second-party authentication, ${ }^{39}$ a second party may prepare and verify the petition. In sum, while section 2242 does not grant an affirmative right of assistance, it does decree that assistance, once obtained, shall be entitled to recognition. ${ }^{40}$ The benefit conferred upon the inmate by the "standing" rationale is, of course, operative only insofar as the inmate has access to parties willing to draft and authenticate petitions. If the statute presents no barrier to the promulgation of a regulation prohibiting inter-inmate assistance,

34 252 F. Supp. at 785.

35 "[A] regulation prohibiting the practice [of jailhouse lawyers] altogether might well be sustained if the state afforded to prison inmates any reasonable alternative, such as an available list of qualified lawyers willing to volunteer their services ....” Id. at 785. Experience indicates that the practice of jailhouse lawyers naturally declines where inmates have ready access to competent legal counsel that will advise them in legal matters. See notes $80-81$ infra and accompanying text, describing the program employed in Oregon.

${ }^{36} 382$ F.2d at 357 .

${ }^{37}$ "[T] ability to draft legal papers as the District Court seems to hold. . . . It seems clear that the situation to which this provision was meant to apply, is one where physical or mental handicaps prevent the prisoner from personally siguing or verifying the petition, not one wherein lack of intelligence or legal training keep him from drafting his own papers." Id.

${ }^{38}$ See id.; 66 Colum. L. Rev. 1542, 1545 (1966); 19 Stan. L. Rev. 887, 888 (1967).

${ }^{30}$ See note 32 supra.

to 66 Colum, L, Rev, 1542, 1545 (1966). 
the present benefit conferred becomes illusory since the state may easily negate the operative effect of section $2242 .{ }^{41}$ The restrictive interpretation acceptable to the Johnson court is inconsistent with the demonstrable need for second-party assistance, ${ }^{42}$ and is not compelled by the cases or legislative history underlying the section. ${ }^{43}$

In addition to rejecting the lower court's interpretation of the habeas corpus statute, the circuit court felt the prison regulation should be upheld as a valid compliment to Tennessee's unauthorized practice of law statute. The court took a literal view of the statutory indication that the drawing of legal papers is included within the practice of law.44 Since Johnson had not been admitted to the state bar, he could not lawfully prepare habeas corpus petitions. The court indicated that it could not allow activities within the prison which would constitute crimes if carried on in society at large. ${ }^{45}$ Finally, the court noted that decisions concerning the right to counsel have always stressed representation by qualified, trained individuals, and that no real benefit would inure to prison inmates by allowing other untrained convicts to assist them. ${ }^{\mathbf{4 6}}$

The circuit court's characterization of the problem in Johnson as one of representation in legal matters is somewhat inaccurate. The assistance ordinarily provided by the inmate lawyer is perhaps more reasonably classified as clerical, for he merely writes a letter to the court setting out the circumstances of the conviction and requesting judicial relief. ${ }^{47}$ In a significant early decision interpreting Tennes-

\footnotetext{
2 Illiterate or mentally handicapped inmates are unlikely to have access to assistance emanating from outside the prison. See 19 STAN. L. REv. 887, 890 (1967); notes 26.28 supra and accompanying text.

$\$ 2$ See notes $20-28$ supra and accompanying text.

s None of the cases cited by the revisers considered a prohibitory regulation similar to the one in Johnson. See note 33 supra. The language of the statute would seem to confirm the interpretation given by the district court. 19 STAN. L. REv. 887, 888 (1967).

" "The 'practice of law' is defined to be and is the appearance as an advocate in a representative capacity or the drawing of papers, pleadings or documents . . . in connection with proceedings pending before any court, commissioner, referee or any body, board, committee or commission constituted by law or having authority to settle controversies. The 'law business' is defined to be and is the advising or counseling for a valuable consideration of any person, firm, association, or corporation . . . " TENN. CODE ANN. §29-302 (1955).

45382 F.2d at 356.

${ }^{6} I d$. at 357 .

"Habeas corpus petitions should contain allegations of fact and not legal arguments. See Johnson v. Rhay, 266 F.2d 530, 534-35 (9th Cir. 1959); Johnson v. Avery, 252 F. Supp. 783, 787 (M.D. Tenn. 1966), rev'd on other grounds, 382 F.2d 353 (6th
} 
see's broad statutory delineation of the practice of law, ${ }^{4 \vec{\sigma}}$ that state's supreme court held that a furniture store clerk who filled in the blank spaces on a prinited form for a writ of replevin was not engaged in prohibited conduct, since the acts were clerical in nature and required none of the intellectual, moral, or professional qualifications of an attorney ${ }^{40}$ Emphasizing that the acts could have been performed by any literate layman, the Tennessee court further held that, in order to come within the statutory prohibition, the conduct in question must have been performed for valuable consideration and must have included an appearance in court in a representative capacity. ${ }^{50}$ Johnson's activities in the present case, therefore, may not have constituted the practice of law in Tennessee, since he was preparing petitions which could have been drafted by any literate layman, no compensation was involved, and no appearance or advocacy was contemplated. ${ }^{51}$

Regardless of the resolution of the statutory argument, the prison regulation in question appears constitutionally infirm. The right to file for habeas corpus is accorded a favored position by the Constitution and common law precedents. ${ }^{52}$ The right is guaranteed by

Cir. 1967); cf. Adamson v. Nash, 218 F. Supp. 841, 845 (W.D. Mo. 1963). Courts, however, liberally interpret habeas petitions. See, e.g., Holiday v. Johnston, 313 U.S. 342, 350 (1941); Murray v. Louisiana, 347 F.2d 825, 827 (5th Cir. 1965); Geaminea v. Nebraska, 206 F. Supp. 308, 315-16 (D. Neb.), appeal dismissed, 308 F.2d 367 (8th Cir. 1962). But cf. Dickerson v. Director, 235 Md. 668, 202 A.2d 765 (1964), in which the court dismissed the petition of a mentally defective inmate for lack of specificity.

${ }^{48}$ See note 44 supra.

to See Haverty Furniture Co. v. Foust, 174 Tenn. 203, 208, 124 S.W.2d 694, 698 (1939).

${ }^{00}$ Id. at 209-14, 124 S.W.2d at 696-98.

Ex Unauthorized practice statutes are traditionally aimed at preventing clients from entrusting their problems to ill-trained advisers. While prisoners deserve protection from bad advice, the traditional reasoning is not strictly applicable to jailhouse lawyers. The drafting of a habeas corpus petition requires minimal legal skill. Also, prisoners may file as many petitions as they desire. Thus, the effect of "bad advice" at some point may be overcome by a later petition. See 19 STAN. L. REv. 887, 891 (1967). Furthermore, it should be recognized that, in the context of the Johnson case, the unauthorized practice argument is essentially a makeweight. If the prison regulation conflicts with a right granted by federal statute, as the district court believed, the unauthorized practice argument must be subordinated. See Sperry v. Florida ex rel. Florida Bar, 373 U.S. 379 (1963). The state interests represented by the unauthorized practice statute have also been subordinated to constitutional provisions. See, e.g., Brotherhood of Railroad Trainmen v. Virginia, 377 U.S. I (1964). In sum, the unauthorized practice statute is often not a strong defensive weapon. The state interest in preserving discipline within its prisons is a much more credible rationale for the type of regulation tested in Johnson. See notes 13-19 supra and accompanying text.

62 Habeas corpus is accorded specific mention in article 1 , section 9 of the United 
federal statute ${ }^{53}$ and included in the substantive law of at least fortyseven state jurisdictions. ${ }^{54}$ The Supreme Court has acknowledged "that the writ of habeas corpus is the precious safeguard of personal liberty and there is no higher duty than to maintain it unimpaired." Therefore, any regulation which tends to inhibit the availability or effectiveness of this remedy should be closely scrutinized.

Vindication of the right to petition for the writ necessarily requires access to the courts, a privilege secured against state intrusion by the due process clause of the fourteenth amendment. ${ }^{50}$ While prison administrators, exercising the broad discretion allowed them in maintaining order and discipline, may curtail prisoner activities which, for persons outside a prison, would be constitutionally protected, no administrative interest will sustain significant interference with the prisoners' access to the courts. ${ }^{57}$ Thus, where

States Constitution, which provides that the privilege of the writ shall not be suspended except when the public safety may require. English subjects were guaranteed the right to personal liberty by the Magna Charta, c. 29, and other acts, notably the Habeas Corpus Act of 1679, 31 Car. 2, c. 2.

5328 U.S.C. $\$ \S 2241-55$ (1964).

5 See Smith v. Bennett, 365 U.S. 708, 712 (1961), discussed in Rossman, Review of Recent Supreme Court Decisions, 47 A.B.A.J. 725, 728 (1961).

st Sce Bowen v. Johnston, 306 U.S. 19, 26 (1939).

${ }^{56}$ Ex parte Hull, 312 U.S. 546 (1941); Kirby v. Thomas, 336 F.2d 462 (6th Cir. 1964); Bolden v. Pegelow, 329 F.2d 95 (4th Cir. 1964). See also Comment, The Rights of Prisoners While Incarcerated, 15 Bufralo L. REv. 397, 414 (1965); Note, Constitutional Rights of Prisoners: The Developing Law, 110 U. PA. L. REv. 985, 987.92 (1962).

${ }^{87}$ Compare Kirby v. Thomas, 336 F.2d 462 (6th Cir. 1964) (upholding regulation forbidding prisoner from mailing papers to initiate civil suit); In re Ferguson, 55 Cal. 2d 663, 361 P.2d 417, 12 Cal. Rptr. 753, cert. denied, 368 U.S. 864 (1961) (Black Muslim prisoners not allowed to hold prayer meetings); and In re Johnson v. Commissioner, 6 App. Div. 2d 920, 175 N.Y.S.2d 689 (1958) (inmate allowed to receivc only those letters from his children which were in their handwriting, as opposed to those penned by their mother), with Ex parte Hull, 312 U.S. 546 (1941) (prison authorities may not fail to forward petitions to the proper court even though they believe the grounds asserted to be insufficient or untrue); Hymes v. Dickson, 232 F. Supp. 796 (N.D. Cal. 1964) (inmates should not have to answer to prison authorities for allegations in complaints addressed to courts); and People v. Superior Court, 273 P.2d 936 (Cal. Dist. Ct. App. 1954) (prison authorities must forward petitions to the court no matter how false the allegations). See also Dewitt v. Pail, 366 F.2d 682 (9th Cir. 1966); Edwards v. Duncan, 355 F.2d 993 (4th Cir. 1966); Haines v. Castle, 226 F.2d 591 (7th Cir. 1955), cert. denied, 350 U.S. 1014 (1956).

Defining the nature and extent of the civil and constitutional rights retained by prisoners is difficult, since pronouncements from courts most often look in a negative direction; that is, the court is usually more anxious to delineate the rights that are taken from the inmate than to elucidate those he retains. A typical and oft-quoted phrase is that of the Supreme Court in Price v. Johnston, 334 U.S. 266, 285 (1948): "Lawful incarceration brings about the necessary withdrawal or limitation of many privileges and rights, a retraction justified by the considerations underlying our penal 
a state prison promulgated a rule requiring that all habeas corpus petitions be approved by the legal investigator for the parole board before being forwarded to the proper court, the rule was held invalid by the Supreme Court. ${ }^{58}$ While conceding the merit of the interests advanced by the prison officials in support of the rule, ${ }^{59}$ the Court firmly asserted that "the state and its officers may not abridge or impair [the] right to apply to a federal court for a writ of habeas corpus." 00

Mental or physical incapacity would not seem to justify derogation of the absoluteness of this right. Yet, while the illiterate or handicapped prisoner may be guaranteed access to the courts, access alone is of little value to him if he lacks the capacity or means effectively to assert his objections. Thus, for those prisoners whose mental or educational level precludes written communications in

system." This hesitance to delineate the affirmative rights retained by the prisoner is further compounded by the traditional reluctance of courts to interfere with prison administration. This reluctance is best understood as a rebuttable presumption of correctness in favor of the rules, regulations, and methods of prison administrators. See McCloskey v. State, 337 F.2d 72 (4th Cir. 1964); Sostre v. McGinnis, 334 F.2d 906 (2d Cir.), cert. denied, 379 U.S. 892 (1964); Hatfield v. Bailleaux, 290 F.2d 632 (9th Cir.), cert. denied, 368 U.S. 862 (1961), noted in 58 Micr. L. REv. 1233 (1960) and 39 Texas L. REv. $228(1960)$. The rule is probably based on several grounds, including the principle of the separation of powers and a lack of judicial expertise in the many and complicated problems involved in confining large numbers of persons with varying degrees of anti-social behavior patterns. Cf. Childs v. Pegelow, 321 F.2d 487 (4th Cir. 1963), cert. denied, 376 U.S. 932 (1964); Seigel v. Ragen, 180 F.2d 785 (7th Cir.), cert. denied, 339 U.S. 990 (1950). It appears that courts will refrain from interference even in the face of substantial doubt as to the necessity for the practices in question. See Landman v. Peyton, 370 F.2d 135, 139 (4th Cir. 1966), cert. denied, 388 U.S. 920 (1967). Recent thinking, however, has indicated both the necessity and desirability of making a positive, affirmative declaration of the constitutional rights of prisoners. See Comment, Beyond the Ken of the Courts: A Critique of Judicial Refusal to Review the Complaints of Convicts, 72 YALE L.J. 506 (1963). Furthermore, the Sixth Circuit has not always been so reluctant to look into prison regulations as in the Johnson case. See Coffin v. Reichard, 143 F.2d 443, 445 (6th Cir. 1944), where the court stressed that it would be diligent in finding ways to protect the retained rights of prisoners.

Es Ex parte Full, 312 U.S. 546 (1941).

to While the court in Hull did not enumerate the grounds advanced by the prison officials in support of the rule requiring administrative screening of inmate petitions, those grounds were probably analogous to those in notes $13,17, \& 18$ supra and accompanying text. Courts allow prison administrators wide discretion in promulgating regulations that intimately affect personal prisoner activities, presumably in deference to administrative expertise in maintaining discipline and order within the prison. Despite this judicial tolerance in most areas, no grounds liave yet been found that will support an apparently reasonable rule requiring prisoners to submit their legal papers to prison officials for screening, thus affirming the absolute nature of the right of access to the courts. See note 57 supra.

00312 U.S. at 549 . 
their own behalf, the right of access must clearly embrace the corollary right to seek and obtain assistance in the preparation of the requisite petitions. In a different context, the Supreme Court quite early held that the right to a fair trial, as preserved in the due process clause of the fourteenth amendment, demanded that in many cases an illiterate or handicapped suspect be provided the services of an attorney. ${ }^{61}$ The Court reasoned that the constitutional right to a fair trial would be meaningless absent some effort to counter the handicaps of the defendant. ${ }^{62}$ Similarly, some degree of outside assistance is necessary to give meaning to the illiterate's right of reasonable access to the courts. ${ }^{03}$ The court in Johnson was not, however, presented with the question of whether the state is compelled to provide affirmative assistance to illiterate prisoners. Rather, the problem in Johnson was the lesser one of the extent to which the state may foreclose the primary means of private assistance while refusing to provide alternatives.

Prison regulations which have made access to judicial review more difficult have often been sustained. It seems clear, for instance, that the prison may limit the times during which prisoners may work on legal materials, ${ }^{84}$ limit the amount of funds which prisoners may use for the purchase of legal documents, ${ }^{65}$ and, in some cases, even deny the prisoners access to legal materials. ${ }^{68}$ On the other hand, regulations and practices which have effectively foreclosed access to judicial review have been consistently invalidated. ${ }^{67}$ The effect of the prison regulation in Johnson goes substantially beyond a mere limitation upon access. By depriving illiterate prisoners of their sole realistic avenue of aid, the regulation parallels in operative effect a decree flatly prohibiting the filing of petititons and is certainly more prohibitory in nature than the practice of administrative screening of petitions condemned in $\mathrm{Hull}_{.}{ }^{88}$

\footnotetext{
${ }^{61}$ See Betts v. Brady, 316 U.S. 455 (1942), discussed in Kamisar, Betts v. Brady Twenty Years Later: The Right to Counsel and Due Process Values, 61 Mictr. L. REv. 219 (1962); cf. Powell v. Alabama, 287 U.S. 45 (1932).

${ }^{83} \mathrm{See} 316$ U.S. at 472-73; cf. Powell v. Alabama, 287 U.S. 45, $71-72$ (1932).

${ }^{63}$ See notes 38-40 supra and accompanying text.

64 Hatfield v. Bailleaux, 290 F.2d 632 (9th Cir.), cert. denied, 368 U.S. 862 (1961).

${ }^{\text {ex }}$ See id. at 638.39.

${ }^{8 B}$ E.g., Oregon ex rel. Sherwood v. Gladden, 240 F.2d 910 (9th Gir. 1957); Grove v. Smyth, 169 F. Supp. 852 (E.D. Va. 1958).

${ }^{\text {or }}$ See note 57 supra.

${ }^{68}$ Ex parte Hull, 312 U.S. 546 (1941). Relying upon the requirements of due
} 
The Tennessee regulation also seems vulnerable to attack as a denial of equal protection of the laws. Traditionally, equal protection has been invoked where some identifiable group has been discriminated against, without rational justification, in such a way as to foreclose to the group some right or privilege available to others. $^{69}$ The Tennessee regulation does not evince, on its face, a clearly discriminatory purpose or an arbitrary classification of groups. However, Griffin v. Illinois ${ }^{70}$ and its progeny established a strong basis for constitutional attack against the type of regulation involved in Johnson. In Griffin the Supreme Court invalidated an Illinois requirement that a convict purchase a transcript of his trial in order to secure full state court appellate review. The Court reasoned that, since the ability to pay the cost of transcripts bears no rational relationship to guilt or innocence, the state could no more discriminate on the basis of poverty than religion, race, or color. ${ }^{71}$ The Griffin rule was later applied in Burns $v$. Ohio ${ }^{72}$ to void a requirement that criminal defendants pay a filing fee in order to docket motions for leave to appeal. The Court drew attention to the fact that there was no basis for assuming that the motions of indigents would be any less meritorious than those brought by other defendants. ${ }^{73}$ The rules announced in Griffin and Burns were extended to state habeas corpus proceedings in Smith $v$. Bennett ${ }^{74}$ wherein the Court voided an Iowa statute requiring a four-dollar filing fee for habeas corpus petitions. The Court felt that to interpose any financial considera-

process, the court in White v. Blackwell, 277 F. Supp. 211 (N.D. Ga. 1967), recently stated that a no-assistance rule, if literally interpreted, would not be legal.

${ }^{\circ}$ See Peterson v. City of Greenville, 373 U.S. 244 (1963), noted in The Supreme Court, 1962 Term, 77 HARv. L. REv. 62, 127-31 (1963) (state action enforcing segregation on basis of race held denial of equal protection); Douglas v. California, 372 U.S. 353 (1963), discussed in Comment, Right to Counsel in Criminal Post-Conviction Review Proceedings, 51 CALIF. L. REv. 970 (1963) and The Supreme Court, 1962 Term, supra at 105-08 (state failure to provide counsel for indigents on mandatory review held denial of equal protection); Baker v. Carr, 369 U.S. 186 (1962), discussed in Note, 30 GEO. WASH. L. REv. 1010 (1962) (state failure to reapportion legislature held denial of equal protection).

${ }^{30} 351$ U.S. 12 (1956), discussed in Kamisar, supra note 61, at 244-54 and Willcox \& Bloustein, The Griffin Case-Poverty and the Fourteenth Amendment, 43 CoRNELr L.Q. 1 (1957).

71351 U.S. at 17 .

2360 U.S. 252 (1959), noted in Rossman, Review of Recent Supreme Court Decisions, 45 A.B.A.J. 1072 (1959).

78360 U.S. at $257-58$.

" 365 U.S. 708 (1961), discussed in Rossman, Review of Recent Supreme Court Decisions, 47 A.B.A.J. 725, 728 (1961). 
tions between an indigent prisoner and his exercise of a state right would deny the prisoner equal protection of the law. ${ }^{75}$ Thus, in each of the above cases, the Court voided state action that discriminated against indigents in such a way as to make inaccessable rights of review and habeas corpus. ${ }^{78}$

Clearly, the practical effect of the prison regulation in Johnson is to deny access to judicial review to another identifiable group-in this case, illiterates rather than indigents. Under the regulation, the inability of the illiterate to petition for habeas corpus is as complete as if the regulation denied him the right of petition on its face. ${ }^{77}$ Furthermore, the detrimental impact of Tennessee's noassistance rule is even more severe than the state procedure in Griffin, since a degree of review was still available to indigents there, albeit on less favorable terms, ${ }^{78}$ or in Smith, where federal courts were still available for habeas corpus proceedings without payment of the four-dollar fee. ${ }^{70}$ Under the circumstances authorized in Johnson, the Tennessee no-assistance rule closes the door to any and all review by habeas corpus for inmates who are unable to draft their own petitions.

\section{ConcLusion}

The above analysis does not mean that Tennessee could not regulate, or even entirely prohibit, practice by jailhouse lawyers. Because of the difficulties created by the presence of these advisers, the state may have a strong interest in adopting a regulatory scheme. However, the plan must not operate to prevent large numbers of prisoners from achieving judicial consideration of their grievances. The experience of other states illustrates that the problems posed by jailhouse lawyers can be met with measures less drastic and offensive than the regulation promulgated by Tennessee.

An acceptable solution to the dual problems of effective access to legal assistance and the practice of jailhouse lawyers lies in the extension of the right to counsel to post-conviction remedies through the development of a state public defender office employing a staff

\footnotetext{
75365 U.S. at 709.

${ }^{70}$ See Kamisar, supra note 61, at 248-54.

${ }^{77}$ Cf. The Supreme Court, 1955 Term, 70 HARv. L. Rev. 83, 127 (1956). Prison regulations directly prohibiting the filing of prisoner appeals have been held violative of equal protection. See Dowd v. United States ex rel. Cook, 340 U.S. 206 (1951); Cochran v. Kansas, 316 U.S. 255 (1942).

78351 U.S. at 13 n.2.

7965 U.S. at 713.
} 
of attorneys to represent inmates in appeal and review proceedings. After instituting such a program, Oregon, for example, reported that the ordinary inmate no longer attempted to draft his own legal papers, or sought assistance from other inmates, since full and competent service was made available without charge by the public defenders office. ${ }^{80}$ Furthermore, the program has reduced the possibility of frivolous appeals since most inmates accept the opinion of the defender as to the strength of their cases and do not attempt to prosecute appeals on their own. ${ }^{81}$

For the state presently unable to afford such a program, an interesting system has been employed in Nebraska with impetus from the federal courts. That state originally had a no-assistance rule similar to the Tennessee regulation. ${ }^{82}$ However, in the course of a habeas corpus proceeding brought by an inmate to secure release from solitary confinement for allegedly violating the rule, the warden was ordered by the court to amend the provision so as to allow assistance. ${ }^{83}$ The prison then established one capable inmate as the writ writer, and furnished him with basic law books and other necessary materials. Inmates are now allowed to consult with the writ writer at scheduled times in the prison library, subject to the warden's permission. ${ }^{84}$ The local federal district court also provides a simple mimeographed habeas corpus form to be used in connection with the above program. The form requests the inmate to supply information on his conviction, appeal, prior habeas corpus petitions, and attorneys, in order to assist the court in determining the relevant facts of his case and his grounds for review. ${ }^{85}$

\footnotetext{
${ }^{80}$ Letter from George W. Randall, Administrator, Oregon State Board of Control, to the Duke Law Journal, Oct. 19, 1967.

${ }^{81}$ Id.

8. See Burnside v. Nebraska, 378 F.2d 915, 916 (8th Cir. 1967).

${ }^{88}$ Id.

84 Letter from Ronald B. Jones, Associate Warden, Nebraska Penal and Correctional Complex, to the Duke Law Journal, Oct. 17, 1967.

${ }^{85}$ Judge Robert Van Pelt of the United States District Court in Lincoln, Nebraska, provides inmates with a mimeographed form for filing habeas corpus petitions. He reports that the use of this form, combined with an appointed inmate to assist other inmates in its preparation, has greatly facilitated the problem of determining which claims are likely to prove meritorious, and, hence, deserving of the appointment of counsel. Letter from Robert Van Pelt, Judge, United States District Court for Nebraska, to the Duke Law Journal, Nov. 7, 1967.

The practice of providing prisoners with forms for habeas corpus petitions apparently began with the Federal District Court for the Northern District of Illinois, and has been followed by a number of other districts. See R. SOKoL, A HaNdBOok of Federal habeas Corpus 53-54, 192-200 (1965).
} 


\section{APPENDIX}

The following information was received in response to a survey undertaken by the Duke Law Journal. Letters were sent to all state and federal prison administrators with a request for information concerning educational achievement, intelligence, and literacy among inmates. Material relating to these items is included in this appendix. Differences in the bases employed and forms of expression, however, preclude a meaningful tabular comparision of jurisdictions.

Discussion of the problems and solutions connected with jailhouse lawyers was encouraged, and responses are incorporated into the body of this note. Of fifty-one inquiries sent, thirty-three replies were received. All correspondence is on file in the offices of the Duke Law Journal.

\section{Selected Characteristics OF PRISON INMATtes BY JURISDiction}

Federal Bureau of Prisons: $51.7 \%$ claim to have completed more than 8 years schooling; $24.6 \%$ test higher than 8 th grade; $19 \%$ below 90 I.Q.; $4 \%$ are either illiterate or have completed less than one year in school.

Alabama: Average of $4 \mathrm{1} / 2$ years school completed; 80 average I.Q.; $10 \%$ illiteracy.

Arizona: $45 \%$ have not completed 8th grade; $3.3 \%$ are illiterate.

California: Average 8 years schooling; I.Q. is average.

Colorado: Average 8 years schooling; average I.Q. is $95.3 ; 6.2 \%$ were confined in mental hospitals prior to prison admission.

Connecticut: Average 6.4 years schooling; average I.Q. is 93.6.

Delaware: Average 7 years schooling; I.Q. is average; $40 \%$ are illiterate.

Florida: $48 \%$ completed less than 9 years education; $25 \%$ are below 80 I.Q.; $1.2 \%$ are mentally disabled.

Illinois: 29.3\% rank in the "Dull Normal" I.Q. range or lower.

Iowa: Information not available.

Louisiana: Average 6 years schooling; average I.Q. is $80 ; 16 \%$ are illiterate.

Michigan: $40 \%$ are below 90 I.Q.

Minnesota: $41 \%$ completed less than 9 years schooling; $29 \%$ are below average I.Q.; $4 \%$ are mentally disabled; $1 \%$ are illiterate.

Mississippi: Information not available.

Missouri: Inmates claim an average of $\mathbf{9}$ years schooling, but achievement tests indicate 7 years.

Nebraska: Average 9 years schooling; average I.Q. is 96. 
New Hampshire: $20 \%$ completed less than 8 years schooling; average I.Q. is between $85-95$; 11 inmates (not percent) are illiterate.

New Jersey: 6-8 years average education; $7-8 \%$ illiteracy.

North Carolina: Inmates claim 8.33 years median education, achievement tests show 4.57 years; $49 \%$ have less than 90 I.Q.; $6.3 \%$ are mentally defective.

North Dakota: Information not available.

Oregon: $6.2 \%$ completed less than 5 years schooling; $34 \%$ rank in the "Dull Normal" I.Q. range or lower; $1 \%$ are mentally defective; $14 \%$ are illiterate at admission, $2 \%$ at release. This is better than the national average, due to prison schools. See note 22 supra and accompanying text.

Pennsylvania: Information not available.

Rhode Island: Information not available.

South Carolina: $60 \%$ completed less than 9 years of school; $30 \%$ are below 80 I.Q.

South Dakota: Inmates claim an average of 9.6 years schooling, achievement tests indicate 8.7 years; average I.Q. is 96 . All statistics are from prison school enrollment only.

Tennessee: Information not available.

Texas: 5.I years average educational achievement; average I.Q. is $86 ; 16 \%$ are illiterate upon admission.

Vermont: Information not available.

Virginia: $14 \%$ are "retarded" with respect to I.Q.; $15 \%$ are illiterate. Washington: 9.8 years median schooling; I.Q. is average.

West Virginia: $54 \%$ completed less than 9 years schooling; $10 \%$ are illiterate (estimate).

Wisconsin: $34.5 \%$ have completed less than 9 years schooling; but $59.4 \%$ rank less than 9 years schooling by test; $19.6 \%$ are in the "Dull Normal" I.Q. range or lower.

Wyoming: $70 \%$ have completed less than 11 years schooling. 